\title{
Inter-simple sequence repeat (ISSR) polymorphism- based analysis of diversity in the freshwater turtle genus Pangshura
}

\author{
Chittaranjan Baruah ${ }^{1}$, M. A. Laskar ${ }^{2}$ and D. K. Sharma ${ }^{3 *}$ \\ ${ }^{1}$ Department of Zoology, Darrang College, Tezpur - 784001, Assam, India. \\ ${ }^{2}$ Department of Biotechnology, St. Anthony's College, Bomfyle Road, Shillong-793001, Meghalaya, India. \\ ${ }^{3}$ Department of Zoology, Bioinformatics Centre, Gauhati University, Guwahati - 781 014, Assam, India.
}

Accepted 10 October, 2012

\begin{abstract}
Assessment of genetic variability among the freshwater turtles is critical to the development of effective conservation strategies. In the present study, analysis of phenetic relationship of the genus Pangshura was studied using inter simple sequence repeat (ISSR) markers to see the concordance of currently available morphological data with genetic data along with spatial pattern of distribution. Ten microsatellite-based primers amplified 156 ISSR markers among 36 individuals belonging to four turtle species Pangshura sylhetensis, Pangshura tecta, Pangshura simithii and Pangshura tentoria, collected from certain localities of Assam, West Bengal and Uttar Pradesh of India. Estimations of Nei's genetic diversity $(\mathrm{h})$, Shannon's Index $(\mathrm{I})$ and Total genetic diversity $\left(\mathrm{H}_{\mathrm{t}}\right)$ reveal the existence of greater genetic diversity in $P$. tentoria and $P$. sylhetensis than in the other two species. However, low values of gene flow $(\mathrm{Nm})$ and of within sample diversity $\left(\mathrm{H}_{\mathrm{s}}\right)$ indicate prevalence of inbreeding in these species groups. The coefficients of differentiation (GST) values divulge that divergence started in the Pangshura species. Projections on the principal components analysis (PCA) plot reflect the distinct genetic identity of these four species. The consensus Neighbour Joining dendogram depicts $P$. sylhetensis, $P$. tecta, and $P$. tentoria as genetically closer to each other than to $P$. smithii.
\end{abstract}

Key words: Differentiation, genetic diversity, inter simple sequence repeat (ISSR), Pangshura, turtle.

\section{INTRODUCTION}

The northern region of India, enriched with wide diversity of freshwater turtles has been designated as priority area of turtle conservation (Shrestha, 2001; Buhlmann et al., 2009). The family Geoemydidae to which the genus Pangshura belongs comprises of many of the highly endangered species (Van Dijk et al., 2000; IUCN, 2011). Most of the Geoemydid turtles are freshwater species and occupy a wide range of habitats, from highly aquatic (Pangshura) to terrestrial (Geoemyda). The genus Pangshura comprises small-sized turtles, having maximum shell length of 20 to $26.5 \mathrm{~cm}$. The species that

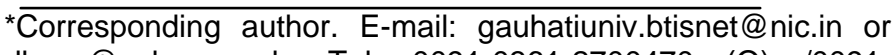
dksgu@yahoo.co.uk. Tel: 0091-0361-2700470 (O) /009194351-47412(M). come under this genus are Pangshura tecta, Pangshura sylhetensis, Pangshura tentoria and Pangshura smithii (Das, 2001). Further, these species are fragmented to sub-species like Pangshura tentoria, Pangshura tentoria circumdata, Pangshura tentoria flaviventer, Pangshura smithii and Pangshura smithii pallidipes. Recent field studies indicate the decline in numbers of these freshwater turtles in the Brahmaputra and Ganga river basins (Baruah, 2010; Baruah et al., 2010; Choudhury et al., 2000). The aim of the present study was the assessment of the genetic diversity based on the polymorphism in inter simple sequence repeat (ISSR) markers (Zietkiewicz et al., 1994) among the freshwater turtles of the genus Pangshura from northeast India, as information regarding morphological and genetic identification of the four species under this genus is lacking. 
Genetic data have been used in turtle conservation to evaluate the genetic variability within and among population (Janzen et al., 1997; Souza et al., 2002; Schwartz and Karl, 2005) to recognize the existence of cryptic taxa (Russello et al., 2005), and to reveal migratory patterns (Bowen and Avise, 1996). Similarly, microsatellites have been used to evaluate the genetic consequences of population bottlenecks (Kuo and Janzen, 2004; Waldick et al., 2002), population sizes, migration rates (Nichols and Freeman, 2004), natal dispersal (Berry et al., 2002; 2004), hybridization (Burns et al., 2003), diversity (Fritz et al., 2008) and also used in wildlife forensics (Avise, 2004).

DNA-based markers have gained popularity in recent years in the assessment of genetic relationship among species. Of these markers, the ISSR markers (Zietkiewicz et al., 1994) are often used in the phenetic studies (Gupta et al., 1994; Wu et al., 1994; Marmi et al., 2006; Fritz et al., 2008; Guicking et al., 2009). These markers being polymorphic (Bornet and Branchard, 2001) and ubiquitous in the genome (Tautz and Renz, 1984), have the advantages of Simple Sequence Repeat (SSR) markers, while bypassing the major obstacle to the development of SSR markers, that is the need to know the flanking sequences. Generally, the ISSRs are scored as dominant markers which are inherited in Mendelian fashion (Ratnaparkhe et al., 1998). The SSR regions scattered evenly throughout the genome (Condit and Hubbell, 1991) and yielding a large number of polymorphic bands, which are interpreted as band present or band absent (Tsumura et al., 1996). The absence of band signifies primer divergence or loss of a locus through the deletion of the SSR site or chromosomal rearrangement (Wolfe et al., 1998).

Friz et al. $(2005,2008)$ examined the evolutionary relationships of five species of the genus Testudo and Cyclemys diversity using the data generated from the inter simple sequence repeat- polymerase chain reaction (ISSR-PCR) genomic nuclear fingerprints. Hence, the ISSR markers are suitable for use in species distinction where extensive information on DNA sequences is not readily available (Meloni et al., 2006). We report here the findings of our ISSR polymorphism-based study on the genetic diversity and phenetic relationship of all the four species and the sub-species within the Indian freshwater turtle genus Pangshura.

\section{MATERIALS AND METHODS}

\section{Study area}

The field work and sample collection were carried out during January, 2008 to March, 2011 in different parts of Assam (including bordering areas of Bangladesh and Bhutan), West Bengal, Uttar Pradesh of India (Table 1, Figure 1). Almost all the target species and their phenotypic variations were captured and used for the analysis of molecular data. Taxonomy and nomenclature were followed after Das $(1995,2002)$ and Praschag et al. (2007).

\section{Sample collection and DNA extraction}

Thirty-six (36) Pangshura samples belonging to four species as presented in Table 1 were sampled by clipping off a tiny piece of the webbing of toes. Tissues were preserved in 95\% ethanol and stored at $-20^{\circ} \mathrm{C}$ until DNA extraction. DNA was extracted using the method of Ausubel et al. (1995) with minor modifications and stored in TE buffer at $-20^{\circ} \mathrm{C}$ until use.

Inter-simple sequence repeat-polymerase chain reaction (ISSRPCR) amplification

Polymerase chain reactions (PCRs) were performed using ten ISSR primers (Table 2), after an initial screening of 19 primers. Primers P4 to P9 were based on turtle microsatellites reported by Aggarwal et al. (2004), Edwards et al. (2003) and Schwartz et al. (2003), with some modifications. Primers P1, P2, P3 and P10 were designed and used by Chen et al. (2009) in grass carp. PCRs were carried out in $20 \mu \mathrm{L}$ of reaction volume containing $20 \mathrm{ng}$ of genomic DNA, $1.0 \mathrm{U}$ Taq polymerase, $200 \mu \mathrm{M}$ dNTP, $1 \mu \mathrm{M}$ primer, and $1 \mathrm{X}$ amplification buffer (containing $2 \mathrm{mM} \mathrm{MgCl}$ ). The condition for amplification was an initial denaturation temperature $94^{\circ} \mathrm{C}$ for five min, followed by 35 cycles of $45 \mathrm{~s}$ at $94^{\circ} \mathrm{C}$, then by $45 \mathrm{~s}$ at appropriate annealing temperature (Table 2) followed by 2 min at $72^{\circ} \mathrm{C}$, and then by a final extension step for 7 min at $72^{\circ} \mathrm{C}$. Amplicons were resolved at $100 \mathrm{~V}$ on $1.8 \%$ agarose gels containing $0.5 \mu \mathrm{g} / \mathrm{ml}$ ethidium bromide. Low range DNA ruler was used as size marker.

\section{Data analysis}

The molecular sizes of the amplicons were measured using the gel documentation software UVItec ver 12.8. Lanes representing the turtle samples were scored for the presence (1) or absence (0) of bands. POPGENE ver. 1.32 (Yeh and Boyle, 1997) was utilized to estimate genetic variability based on Nei's (1973) coefficient of gene differentiation $\left(\mathrm{G}_{\mathrm{ST}}\right)$. The software was also used to calculate observed alleles, effective alleles, Shannon's information index (I), total genetic diversity $(\mathrm{Ht})$, sample genetic diversity $(\mathrm{Hs})$ and estimated gene flow $(\mathrm{Nm})$.

The relatedness among turtle samples was analysed based on the Neighbour Joining algorithm (Saitou and Nei, 1987). The matrix of binary characters was bootstrapped using the software Phyltools (Buntjer, 2001). Re-sampling was done 1000 times using 35\% bootstrap values. Phytools was then used to generate distance matrices based on Nei's coefficient (Nei and Li, 1979); $S=2 a /(a+b)$ $+(a+c)$, where, $a=$ band $(s)$ shared by individual $x$ and $y ; b=$ bands amplified in individual $\mathrm{x}$ but not in $\mathrm{y}$; $\mathrm{c}=$ band(s) amplified in individual $y$ but not in $x$. Distance was estimated as 1-S. The Consensus Neighbour Joining Tree was prepared using the software Phylip ver 3.1 (Felsenstein, 2004). Geneious Pro ver 4.8 (Drummond et al., 2010) was used to obtain a presentable consensus tree.

Principal components analysis (PCA) of the original binary matrix was also performed sequentially by using the modules of NTSYSpc ver 2.20r (Rohlf, 2005): stand, simint, eigen and project.

\section{RESULTS}

\section{Inter-simple sequence repeat (ISSR) amplification}

The primers generated 156 clear and distinguishable ISSR bands, where sizes ranged from 0.2 to $2.836 \mathrm{~kb}$ 
Table 1. Pangshura samples used in the present studied.

\begin{tabular}{|c|c|c|c|}
\hline Sample & Taxon & Place of collection & GPS Location \\
\hline T52 & P. sylhetensis & $\begin{array}{l}\text { Kushiara River, Bhangabazar, Karimganj } \\
\text { district, Assam }\end{array}$ & $24^{\circ} 51^{\prime} 39.2238^{\prime \prime} \mathrm{N}, 92^{\circ} 28^{\prime} 55.3865^{\prime \prime E}$ \\
\hline T28 & P. sylhetensis & Biswanath Ghat, Assam & $26^{\circ} 39^{\prime} 31.46^{\prime \prime} \mathrm{N}, 93^{\circ} 10^{\prime} 18.91^{\prime \prime} \mathrm{E}$ \\
\hline T8 & P. sylhetensis & $\begin{array}{l}\text { Jia Bharali River (Nameri National Park), } \\
\text { Assam }\end{array}$ & $26^{\circ} 55^{\prime} 20.22^{\prime \prime} \mathrm{N}, 92^{\circ} 50^{\prime} 27.12^{\prime \prime} \mathrm{E}$ \\
\hline $\mathrm{C} 10$ & P. sylhetensis & Kuruwa Ghat, Darrang district, Assam & $26^{\circ} 13^{\prime} 32.79^{\prime \prime} \mathrm{N}, 91^{\circ} 46^{\prime} 39.74^{\prime \prime} \mathrm{E}$ \\
\hline Т3 & P. sylhetensis & Buxa Wildlife Sanctuary, West Bengal & $26^{\circ} 50^{\prime} 17.05^{\prime \prime N}, 89^{\circ} 50^{\prime} 13.83^{\prime \prime} \mathrm{E}$ \\
\hline $\mathrm{T7}$ & P. tecta & Hajo, Kamrup district, Assam & $26^{\circ} 14^{\prime} 41.1^{\prime \prime} \mathrm{N}, 91^{\circ} 31^{\prime} 37.2^{\prime \prime} \mathrm{E}$ \\
\hline $\mathrm{C} 7$ & P. tecta & Gomrighat, Sonitpur district, Assam & $26^{\circ} 44^{\prime} 47.93^{\prime \prime} \mathrm{N}, 93^{\circ} 38^{\prime} 45.45^{\prime \prime} \mathrm{E}$ \\
\hline $\mathrm{C} 4$ & P. tecta & $\begin{array}{l}\text { Kushiara River, Karimganj district, India- } \\
\text { Bangladesh border }\end{array}$ & $24^{\circ} 52^{\prime} 37.53 .41^{\prime \prime N}, 92^{\circ} 31^{\prime} 5.16 .25^{\prime \prime E}$ \\
\hline $\mathrm{T} 2$ & P. smithii & $\begin{array}{l}\text { Brahmaputra, Bhurhachapari Wildlife } \\
\text { Sanctuary }\end{array}$ & $26^{\circ} 33^{\prime} 12.7^{\prime \prime} \mathrm{N}, 92^{\circ} 21^{\prime} 32.6^{\prime \prime} \mathrm{E}$ \\
\hline T50 & P. smithii & Deeporbeel, Kamrup district, Assam & $26^{\circ} 07^{\prime} 02^{\prime \prime} \mathrm{N} \quad 91^{\circ} 38^{\prime} 40^{\prime \prime} \mathrm{E}$ \\
\hline $\mathrm{T} 1$ & P. smithii & Tengatoli char, Morigaon, Assam & $26^{\circ} 29^{\prime} 016^{\prime \prime} \mathrm{N}, 92^{\circ} 20^{\prime} 41.5^{\prime \prime} \mathrm{E}$ \\
\hline $\mathrm{C} 12$ & P. smithii & Biswanath Ghat, Sonitpur district, Assam & $26^{\circ} 46^{\prime} 30.74^{\prime \prime} \mathrm{N}, 93^{\circ} 32^{\prime} 04.86^{\prime \prime} \mathrm{E}$ \\
\hline C15 & P. smithii pallidipes & Ganga river, Farrukhabad, Uttar Pradesh & $27^{\circ} 12^{\prime} 50.8^{\prime \prime} \mathrm{N}, 79^{\circ} 41^{\prime} 34.6^{\prime \prime} \mathrm{E}$ \\
\hline T16 & P. tentoria circumdata & Yamuna river, Etawah, Uttar Pradesh & $26^{\circ} 45^{\prime} 13.44 .53^{\prime \prime N}, 79^{\circ} 0^{\prime} 28.20 .74 " \mathrm{E}$ \\
\hline $\mathrm{T} 15$ & P. tentoria circumdata & Yamuna river, Uttar Pradesh & $26^{\circ} 44^{\prime} 37.5749^{\prime \prime N}, 79^{\circ} 0^{\prime} 3.488^{\prime \prime E}$ \\
\hline $\mathrm{T} 12$ & P. tentoria circumdata & Ganga river, Farrukhabad, Uttar Pradesh & $27^{\circ} 14^{\prime} 17.7^{\prime \prime} \mathrm{N}, 79^{\circ} 40^{\prime} 27.1 " \mathrm{E}$ \\
\hline $\mathrm{T} 13$ & P. tentoria circumdata & Ganga river, Farrukhabad, Uttar Pradesh & $27^{\circ} 13^{\prime} 20.4^{\prime \prime} \mathrm{N}, 79^{\circ} 42^{\prime}$ 51.2"E \\
\hline $\mathrm{T} 27$ & P. tentoria flaviventer & Lahorighat, Morigaon district, Assam & $26^{\circ} 27^{\prime} 00.1^{\prime \prime} \mathrm{N}, 92^{\circ} 15^{\prime} 22.2^{\prime \prime} \mathrm{E}$ \\
\hline T49 & P. tentoria & Hajo, Kamrup, Assam & $26^{\circ} 14^{\prime} 41.1^{\prime \prime} \mathrm{N}, 91^{\circ} 31^{\prime} 37.2^{\prime \prime} \mathrm{E}$ \\
\hline T26 & P. tentoria & $\begin{array}{l}\text { Dimbur Char, Lahorighat, Morigaon district, } \\
\text { Assam }\end{array}$ & $26^{\circ} 26^{\prime} 31.5^{\prime \prime} \mathrm{N}, 92^{\circ} 16^{\prime} 08.3^{\prime \prime} \mathrm{E}$ \\
\hline
\end{tabular}

(Table 2). The number of bands per primer ranged from 9 to 24 with a mean of 15.6 bands per primer. Primers 1, 4, 6 and 9 amplified monomorphic markers (Table 2). Primer 3 revealed three markers of $0.615,0.666$ and $0.722 \mathrm{~kb}$ sizes and Primer 5 revealed two markers of 0.52 and $0.592 \mathrm{~kb}$ sizes that were common to both the $P$. smithii subspecies (Figure 2). Primer 5 also amplified two markers of 0.541 and $0.949 \mathrm{~kb}$ sizes that were present in all the three $P$. tentoria subspecies.

The highest number of bands was generated from the primer P10. The highest percentage of polymorphism $(100 \%)$ was generated from the primers P2, P3 and P5 (Table 2). The number of polymorphic bands produced per primer ranged between 6 (P9) to 23 (P10). Out of the 145 polymorphic bands, $P$. sylhetensis had 22 (highest) numbers of unique polymorphic bands followed by 20 in $P$. tentoria, 18 in $P$. tentoria circumdata, 15 each in $P$. smithii and $P$. tentoria flaviventer, 11 in $P$. tecta and 7 in $P$. smithii pallidipes (Table 3). The ISSR banding patterns were amplified by seven primers (Figure 2).

The band profiles generated by ISSR primers showed polymorphism among the Pangshura samples. The extent of polymorphism varied. The percentage polymorphic loci were calculated to be $38.59,24.46$, 27.72 and 47.83 for $P$. sylhetensis, $P$. tecta, $P$. smithii and $P$. tentoria respectively.

\section{Genetic variability revealed through inter-simple sequence repeat (ISSR) markers}

A summary of genetic variation statistics for all loci are presented in Table 4. Average numbers of alleles observed in $P$. sylhetensis, $P$. tecta, $P$. smithii and $P$. tentoria were $1.34 \pm 0.49,1.24 \pm 0.43,1.26 \pm 0.45$ and $1.48 \pm 0.5$ respectively, while it was $2.0 \pm 0.0$ when all four Pangshura species were taken together (Table 5 ). The genetic diversity in the four Pangshura species is presented in Tables 5 and 6.

\section{Phenetic relationship among the test species}

Genetic similarity and distance values based on Nei's original (Nei, 1972) and unbiased (Nei, 1978) measures are presented in Table 6. In the present study, each species of Pangshura is considered as a single population and the genetic distances among the four 


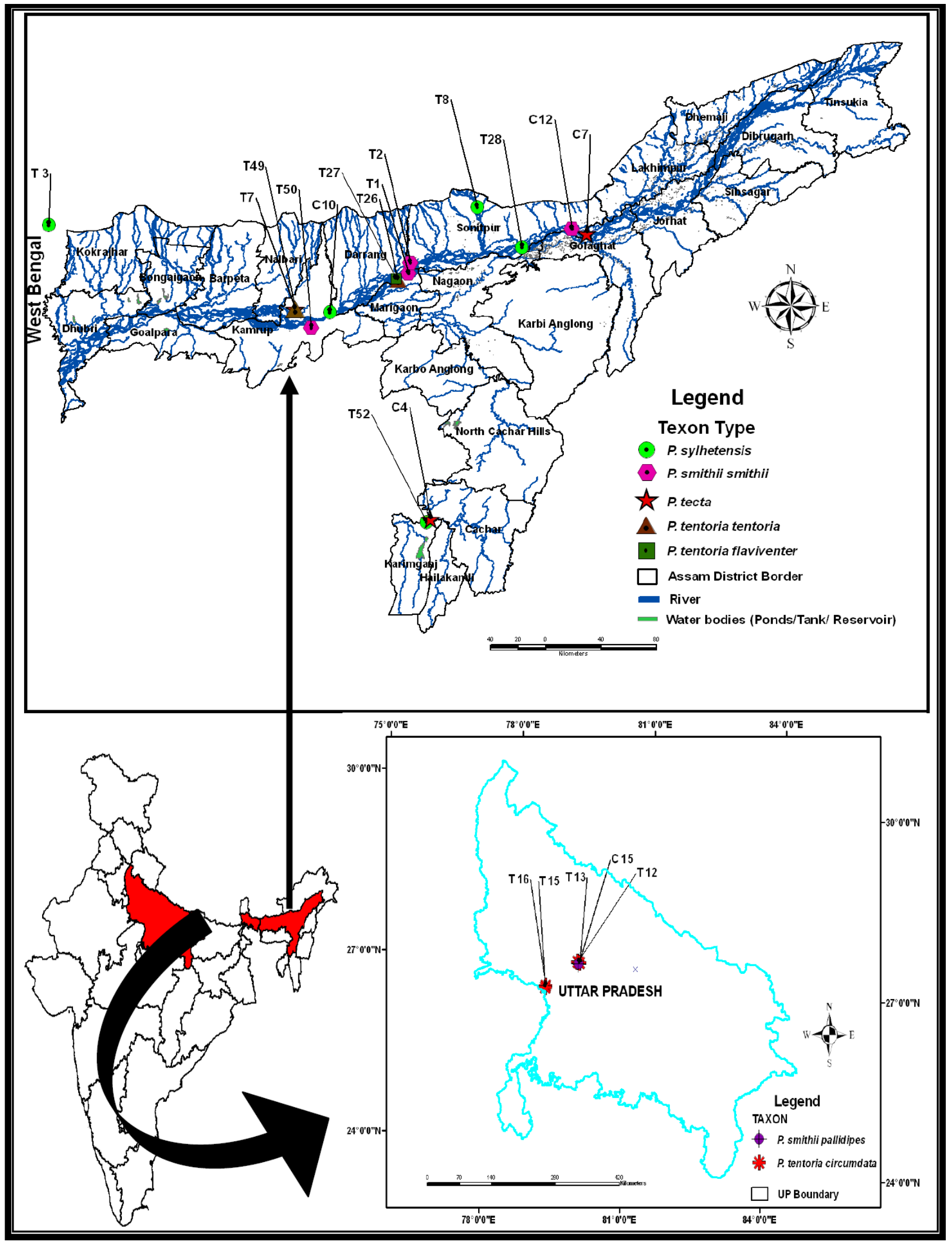

Figure 1. Map showing the location of sample collection sites in Assam (Including Assam-Bangladesh Border, Assam-Bhutan Border and part of West Bengal) and Uttar Pradesh. 
Table 2. ISSR amplicons.

\begin{tabular}{llcccc}
\hline Primer & Primer sequence $\left(\mathbf{5}^{\prime}-\mathbf{3}^{\prime}\right)$ & $\mathbf{T m}\left({ }^{\circ} \mathbf{C}\right)$ & Total bands & Polymorphism \% & Amplicon size range $(\mathbf{k b})$ \\
\hline P1 & 5'(GA)8YT 3' & 48 & 19 & 94.74 & $0.2-1.693$ \\
P2 & 5'(GATA)2(GACA) $3^{\prime}$ & 46 & 22 & 100 & $0.4-2.836$ \\
P3 & 5'(ATG)6 3' & 52 & 16 & 100 & $0.3-1.279$ \\
P4 & 5'(TC)8YG3' $^{\prime}$ & 52 & 21 & 95.24 & $0.255-01.182$ \\
P5 & 5' (TC)8HT 3' & 50 & 15 & 100 & $0.508-1.152$ \\
P6 & 5' (TC)8BG 3' & 52 & 11 & 90.91 & $0.353-1.15$ \\
P7 & 5' (TG)8RT 3' & 50 & 9 & 100 & $0.409-1.083$ \\
P8 & 5' YG(GT)8 3' & 52 & 10 & 100 & $0.574-0.991$ \\
P9 & 5' HR((TG)8 3' & 50 & 9 & 77.78 & $0.611-1.091$ \\
P10 & 5'(AG)8YT 3' & 47 & 24 & 100 & $0.227-1.231$ \\
Pooled values & & & 156 & 100 & \\
\hline
\end{tabular}

$\mathrm{H}=$ non $-\mathrm{G} ; \mathrm{V}=$ non $-\mathrm{T} ; \mathrm{B}=$ non $-\mathrm{A} ; \mathrm{Y}=$ pyrimidine; $\mathrm{R}=$ purine.

Pangshura species ranged from 0.14 to 0.23 . The shortest distance $(0.14)$ existed between $P$. smithii and $P$. tentoria. The longest genetic distance $(0.23)$ existed between $P$. smithii and $P$. tecta. The genetic identity value ranged from 0.79 to 0.87 (Table 7 ).

The Neighbor-Joining ( $\mathrm{NJ}$ ) consensus tree is depicted in Figure 3. The species were grouped into three clusters. Cluster I comprised of $P$. tecta and $P$. sylhetensis. Topology of the cluster indicates that genetic diversity exists between the two species.

Both the species formed two distinct sub-clusters with 81 and $100 \%$ bootstrap support for $P$. tecta and $P$. sylhetensis respectively. Diversity existed among the $P$. sylhetensis samples. $P$. sylhetensis from Bishwanathgath (T28) and Jia Bharali (T8) from the state of Assam were clustered together with $83 \%$ bootstrap support. The $P$. sylhetensis samples from Kuruwaghat $(\mathrm{C} 10)$ of northern Assam and Kushiara River (T 52) bordering Bangladesh were in the same cluster. However, $P$. sylhetensis of Buxa Wildlife Sanctuary (T3) of West Bengal formed a distinct clade within the $P$. sylhetensis group with $81 \%$, bootstrap separation. In the P. tecta sub-cluster of Hajo (T7) and Gomerighat (C7), samples were grouped together with $100 \%$ bootstrap support, while the Kushiara river sample (C4) formed a monophyletic branch at $100 \%$ bootstrap separation.

All the three currently recognized subspecies of $P$. tentoria were clubbed in the clusters II with bootstrap separation $64 \%$. P. tentoria sample collected from Hajo (T49) was on a monophyletic branch of the clade. $P$. tentoria (T 26) and $P$. tentoria flaviventer (T27) samples from Lahorighat were clustered together with $78 \%$ bootstrap support. Samples of $P$. tentoria circumdata collected from the Ganga (T12, T13) and Yamuna rivers (T15, T16) at different sites of Uttar Pradesh (Table 1) reflected their geographical distance from the Pangshura samples of Assam. One of the $P$. tentoria circumdata samples (T13) collected from the Ganga River at
Farrukhabad, Uttar Pradesh was on a monophyletic branch (Figure 3).

Two subspecies of $P$. smithii were clustered together in cluster III. The $P$. smithii samples from Depor beel (T50) and Tengatoli (T1) were closer than the other samples. The $P$. smithii samples collected from Burachapari (T2) and Biswanathghat (C12) formed monophyletic branches. On the other hand, the samples of $P$. smithii pallidipes from Farrukhabad, Uttar Pradesh also formed monophyletic branch with $53 \%$ bootstrap separation.

The genetic interrelationships among Pangshura samples were projected on the PCA plot (Figure 4) and those depicted by the consensus $\mathrm{NJ}$ tree were similar; but were better represented on the plot. The subspecies of $P$. tentoria and that of $P$. simithii were well-separated by the first and the second principal components, however, their phenetic relationship with the subspecies of $P$. tecta, and $P$. sylhetensis was less defined. The subspecies of $P$. tecta and those of $P$. sylhetensis are projected as being closer to one another than they are either to the subspecies of $P$. tentoria or $P$. smithii.

\section{DISCUSSION}

Amplification of a large number of polymorphic ISSR bands (77.78 to $100 \%)$ indicates the existence of genetic diversity in the four Pangshura species. The average values of the observed and effective alleles, percentage polymorphic loci, Nei's gene diversity (h), Shannon's information index $(\mathrm{I})$, total genetic diversity $\left(\mathrm{H}_{\mathrm{t}}\right)($ Table 5$)$ all reveal that the highest polymorphism is present in $P$. tentoria followed by $P$. sylhetensis.

The high $\mathrm{G}_{\mathrm{ST}}$ values and very low $\mathrm{Nm}$ values (Table 5) for all species indicate that they are in a high state of differentiation; $\mathrm{G}_{\mathrm{ST}}>0.25$ and $\mathrm{Nm}<1.0$ are threshold values beyond which significant population differentiation occurs (Kar et al., 2005). The PCA plot (Figure 4) also 


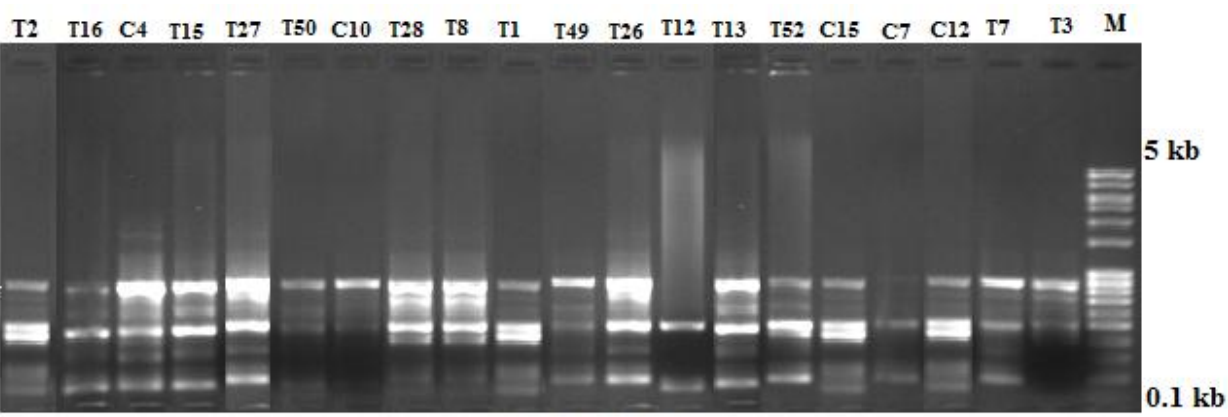

P1: 5'(GA)8YT 3'

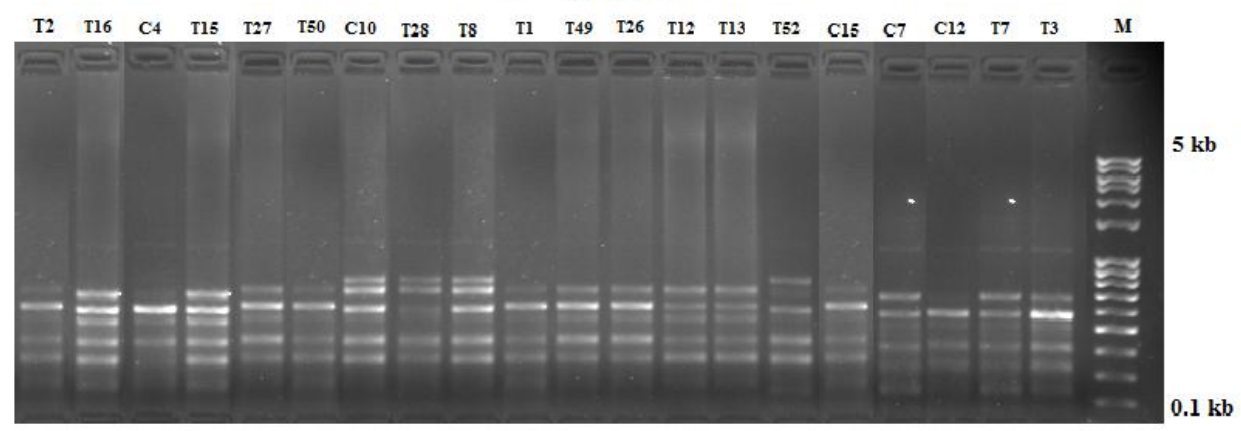

P4: 5'(TC)8YG3'

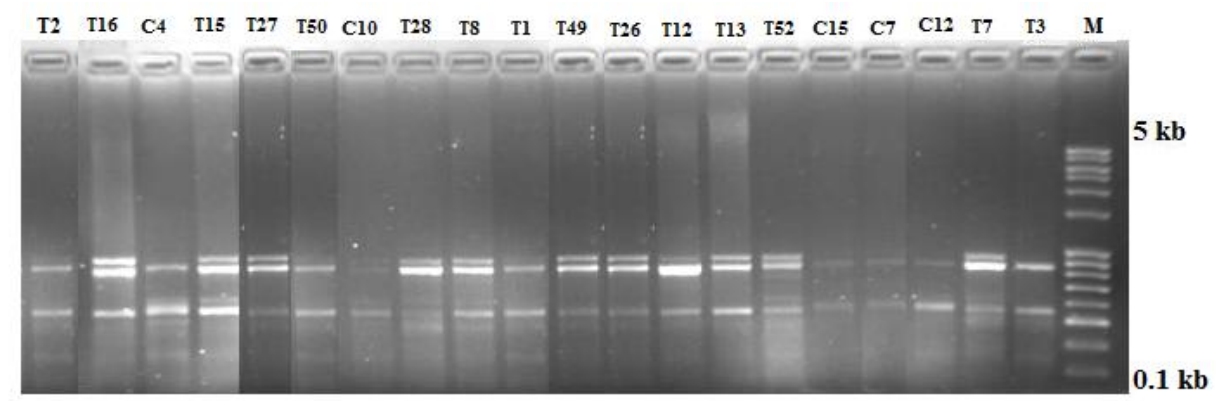

P5: 5' (TC)8HT 3'

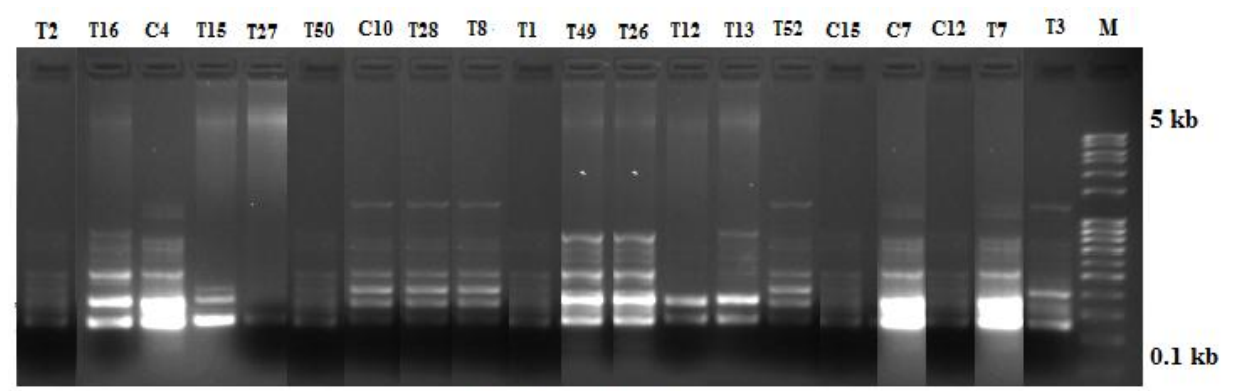

P10: 5'(AG)8YT 3'

Figure 2. ISSR amplification profiles using primers $P 1, P 4, P 5$ and $P 10$, respectively. Pangshura samples with respective sample code are in lanes 1-20; M, 100 bp DNA marker (range 0.1 to $5 \mathrm{~kb}$ ).

indicates the genetic distinctness of the four species. Differentiation might have occurred probably only due to genetic divergence through the evolutionary courses. The Neighbour Joining dendogram (Figure 3) presents the genetic interrelatedness of the Pangshura samples. The $100 \%$ bootstrap separation of $P$. smithii samples (cluster
III) implies this species is more distant from the other two species. The $\mathrm{G}_{\mathrm{ST}}$ values presented in Table 5 supports this result. Nei's measures of genetic identity and genetic distance (Table 7) are also in broad agreement of phenetic relationship that the $\mathrm{NJ}$ tree presents.

Of the primers, P1, P2, P3 and P10 were used earlier 
Table 3. Pangshura species- specific unique ISSR bands.

\begin{tabular}{lccc}
\hline Species & Number of unique bands & Unique Band size (kb) & Primer name \\
\hline P. tecta & 6 & $0.508,0.575$ & $\mathrm{P} 5$ \\
& & $0.227,0.663,0.779,1.046$ & $\mathrm{P} 10$ \\
& & 0.65 & $\mathrm{P} 1$ \\
P. sylhetensis & 10 & $0.3,0.565$ & $\mathrm{P} 3$ \\
& & $0.566,0.818,0.975$ & $\mathrm{P} 5$ \\
& & $0.348,0.419,0.688,1.231$ & $\mathrm{P} 10$ \\
P. smithii & 5 & $0.615,0.666,0.722$ & $\mathrm{P} 3$ \\
& & $0.52,0.592$ & $\mathrm{P} 5$ \\
P.tentoria & 2 & $0.541,0.949$ & $\mathrm{P} 5$ \\
\hline
\end{tabular}

Table 4. Observed and effective number of alleles in the four Pangshura species for all primers.

\begin{tabular}{ccccccccc}
\hline \multirow{2}{*}{ Primer } & \multicolumn{2}{c}{ Alleles in $\boldsymbol{P}$. sylhetensis } & \multicolumn{2}{c}{ Alleles in $\boldsymbol{P}$. tecta } & \multicolumn{2}{c}{ Alleles in $\boldsymbol{P}$. smithii } & \multicolumn{2}{c}{ Alleles in $\boldsymbol{P}$. tentoria } \\
\cline { 2 - 9 } & Observed & Effective & Observed & Effective & Observed & Effective & Observed & Effective \\
\hline P1 & $1.35 \pm 0.5$ & $1.21 \pm 0.4$ & $1.17 \pm 0.4$ & $1.1 \pm 0.2$ & $1.17 \pm 0.4$ & $1.1 \pm 0.2$ & $1.43 \pm 0.5$ & $1.22 \pm 0.3$ \\
P2 & $1.3 \pm 0.5$ & $1.13 \pm 0.3$ & $1.28 \pm 0.45$ & $1.1 \pm 0.2$ & $1.28 \pm 0.45$ & $1.1 \pm 0.24$ & $1.48 \pm 0.5$ & $1.13 \pm 0.2$ \\
P3 & $1.3 \pm 0.48$ & $1.17 \pm 0.32$ & $1.1 \pm 0.23$ & $1.0 \pm 0.04$ & $1.16 \pm 0.37$ & $1.09 \pm 0.25$ & $1.47 \pm 0.5$ & $1.25 \pm 0.3$ \\
P4 & $1.1 \pm 0.32$ & $1.04 \pm 0.15$ & $1.03 \pm 0.19$ & $1.0 \pm 0.03$ & $1.24 \pm 0.44$ & $1.09 \pm 0.21$ & $1.48 \pm 0.51$ & $1.17 \pm 0.21$ \\
P5 & $1.5 \pm 0.51$ & $1.31 \pm 0.39$ & $1.5 \pm 0.51$ & $1.26 \pm 0.3$ & $1.7 \pm 0.38$ & $1.1 \pm 0.28$ & $1.33 \pm 0.48$ & $1.2 \pm 0.18$ \\
P6 & $1.11 \pm 0.33$ & $1.06 \pm 0.24$ & $1.11 \pm 0.33$ & $1.08 \pm 0.25$ & $1.18 \pm 0.39$ & $1.08 \pm 0.18$ & $1.18 \pm 0.39$ & $1.05 \pm 0.13$ \\
P7 & $1.33 \pm 0.49$ & $1.23 \pm 0.36$ & $1.08 \pm 0.29$ & $1.04 \pm 0.12$ & $1.42 \pm 0.51$ & $1.29 \pm 0.4$ & $1.67 \pm 0.49$ & $1.28 \pm 0.32$ \\
P8 & $1.78 \pm 0.44$ & $1.38 \pm 0.37$ & $1.56 \pm 0.53$ & $1.35 \pm 0.39$ & $1.55 \pm 0.53$ & $1.38 \pm 0.46$ & $1.78 \pm 0.44$ & $1.31 \pm 0.26$ \\
P9 & $1.98 \pm 0.3$ & $1.47 \pm 0.31$ & $1.36 \pm 0.5$ & $1.29 \pm 0.44$ & $1.64 \pm 0.5$ & $1.41 \pm 0.44$ & $1.64 \pm 0.5$ & $1.49 \pm 0.48$ \\
P10 & $1.82 \pm 0.4$ & $1.44 \pm 0.37$ & $1.64 \pm 0.5$ & $1.35 \pm 0.36$ & $1.45 \pm 0.52$ & $1.25 \pm 0.37$ & $1.74 \pm 0.47$ & $1.43 \pm 0.42$ \\
\hline
\end{tabular}

Table 5. Genetic parameters for the four species of genus Pangshura.

\begin{tabular}{lccccc}
\hline Genetic parameter & $\boldsymbol{P}$ s sylhetensis & $\boldsymbol{P .}$ tecta & $\boldsymbol{P .}$ smithii & $\boldsymbol{P . \text { tentoria }}$ & Overall \\
\hline Percentage polymorphic loci & 38.59 & 24.46 & 27.72 & 47.83 & 100 \\
Number of observed alleles: $\mathrm{na}$ & $1.34 \pm 0.49$ & $1.24 \pm 0.43$ & $1.26 \pm 0.45$ & $1.48 \pm 0.5$ & $2.0 \pm 0.0$ \\
Number of effective alleles: $\mathrm{ne}$ & $1.2 \pm 0.33$ & $1.13 \pm 0.26$ & $1.15 \pm 0.29$ & $1.22 \pm 0.31$ & $1.34 \pm 0.3$ \\
Nei's genetic diversity: $\mathrm{h}$ & $0.12 \pm 0.12$ & $0.08 \pm 0.15$ & $0.09 \pm 0.16$ & $0.14 \pm 0.17$ & $0.22 \pm 0.16$ \\
Shannon's information index: $\mathrm{I}$ & $0.19 \pm 0.26$ & $0.12 \pm 0.22$ & $0.13 \pm 0.24$ & $0.22 \pm 0.25$ & $0.36 \pm 0.21$ \\
Total genetic diversity $\left(\mathrm{H}_{\mathrm{t}}\right)$ & $0.13 \pm 0.03$ & $0.1 \pm 0.03$ & $0.09 \pm 0.03$ & $0.16 \pm 0.04$ & $0.22 \pm 0.03$ \\
Sample genetic diversity $\left(\mathrm{H}_{\mathrm{s}}\right)$ & $0.01 \pm 0.01$ & $0.01 \pm 0.01$ & $0.004 \pm 0.04$ & $0.03 \pm 0.03$ & $0.11 \pm 0.01$ \\
Estimated gene flow $\left(\mathrm{N}_{\mathrm{m}}\right)$ & 0.04 & 0.05 & 0.02 & 0.09 & 0.46 \\
Gene differentiation $\left(\mathrm{G}_{\mathrm{ST}}\right)$ & 0.93 & 0.91 & 0.96 & 0.84 & 0.52 \\
\hline
\end{tabular}

in grass carp (Chen et al., 2009); P10 showed better cross-species amplification than the others. The Nei's Fstatistics and Shannon's information index values obtained due to $\mathrm{P} 10$ were comparable to the values obtained due to the primers P4, P5, P6, P7, P8 and P9 (Table 6 ) that were designed and slightly modified by us 
Table 6. Nei's F-statistics and Shannon's information index in Pangshura species for all ISSR primers.

\begin{tabular}{cccccc}
\hline Primer & $\begin{array}{c}\text { Overall gene } \\
\text { diversity }\left(\mathbf{H}_{\mathbf{t}}\right)\end{array}$ & $\begin{array}{c}\text { Within sample } \\
\text { gene diversity }\left(\mathbf{H}_{\mathbf{s}}\right)\end{array}$ & $\begin{array}{c}\text { Gene } \\
\text { differentiation }\left(\mathbf{G}_{\mathbf{S T}}\right)\end{array}$ & $\begin{array}{c}\text { Gene diversity } \\
(\mathbf{h})\end{array}$ & $\begin{array}{c}\text { Shannon's } \\
\text { information index }(\mathbf{l})\end{array}$ \\
\hline P1 & 0.16 & 0.09 & 0.42 & 0.12 & 0.18 \\
P2 & 0.15 & 0.08 & 0.46 & 0.15 & 0.27 \\
P3 & 0.24 & 0.08 & 0.66 & 0.16 & 0.25 \\
P4 & 0.19 & 0.05 & 0.74 & 0.19 & 0.31 \\
P5 & 0.22 & 0.13 & 0.42 & 0.22 & 0.35 \\
P6 & 0.29 & 0.04 & 0.85 & 0.28 & 0.44 \\
P7 & 0.24 & 0.13 & 0.48 & 0.24 & 0.39 \\
P8 & 0.36 & 0.21 & 0.39 & 0.34 & 0.52 \\
P9 & 0.32 & 0.23 & 0.27 & 0.31 & 0.48 \\
P10 & 0.29 & 0.22 & 0.24 & 0.28 & 0.43 \\
\hline
\end{tabular}

Table 7. Nei's original (1972) and unbiased (1978) measures of genetic identity and genetic distance among the four Pangshura species.

\begin{tabular}{lcccc}
\hline Pangshura species & P. sylhetensis & P.tecta & P. smithii & P. tentoria \\
\hline P. sylhetensis & - & $0.79(0.8)$ & $0.82(0.83)$ & $0.84(0.85)$ \\
P.tecta & $0.23(0.22)$ & - & $0.79(0.79)$ & $0.84(0.84)$ \\
P. smithii & $0.19(0.19)$ & $0.23(0.23)$ & - & $0.87(0.88)$ \\
P. tentoria & $0.17(0.17)$ & $0.18(0.17)$ & $0.14(0.13)$ & - \\
\hline
\end{tabular}

Genetic identity (above diagonal) and genetic distance (below diagonal); figures in parentheses indicate the unbiased measures values.

based on earlier reports on turtle microsatellites by Aggarwal et al. (2004), Edwards et al. (2003) and Schwartz et al. (2003).

The PCA result reveals that a close relation within the respective $P$. tentoria could not be expected. From the $P$. sylhetensis group, samples from West Bengal and Kushiara River bordering to Bangladesh are placed near to the $P$. tecta group, representing a close genetic relationship between the two species (Figure 4). The analysis of species specific unique ISSR amplicons of the present study (Table 2) along with the genetic parameters (Table 5), the correlation of PCA plot and neighbour joining tree reveal that the genetic diversity among the Pangshura could be well inferred.

Praschag et al. (2007) sampled $P$. sylhetensis and $P$. tentoria from Assam (Northeast India) to construct phylogeny of endangered Southeast Asian turtles including Pangshura. However, their study was based on patchy taxon sampling and could not establish any distinctness between the subspecies of $P$. smithii and $P$. tentoria with the help of cyt $b$ gene dataset. The present study has established that in order to establish the variation in the genome of Pangshura species, ISSR appear as powerful tool. These variations support the validity of the morphologically weakly defined subspecies $P$. tentoria and $P$. tentoria circumdata as well as $P$. smithii and $P$. smithii pallidipes. Although few cross-species microsatellites could be used for genetic diversity of Pangshura, the availability of species-specific markers is highly desirable for population structure assessments. These microsatellites thus provide efficient genetic markers to understand the population structure, phylogeography and species relationships of Pangshura and other freshwater turtle species.

\section{Conclusion}

Our study reveals the existence of a narrow genetic base for all the four turtle species, which we attribute to inbreeding. It is necessary to formulate conservation strategies in terms of protection of the habitat sites to minimize the reduction of gene pool, which might be the probable cause of inbreeding.

In-situ egg hatching of eggs followed by headstarting of those species can also be undertaken as a part of conservation strategy. Future work should focus on finer scale genetic analyses in order to gain a better baseline 


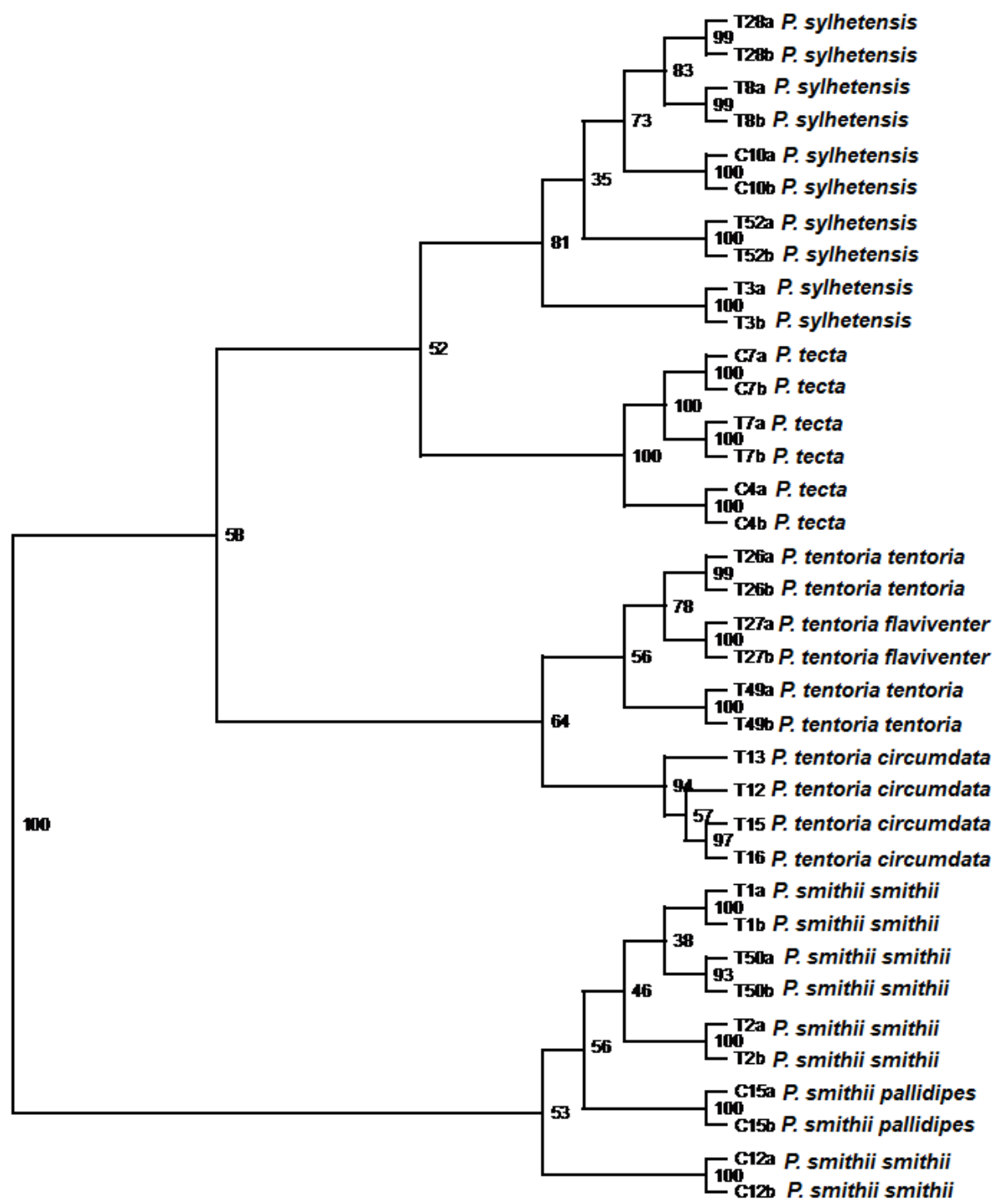

Figure 3. Neighbor-Joining Consensus Tree generated after bootstrap analysis of ISSR data. Bootstrap support values, in percentages, based on 1000 replications are presented. Clusters are indicated in roman numerals. [T28 ( $P$. sylhetensis, Biswanathghat); T8 $(P$. sylhetensis, Jia Bharali river); C10 ( $P$. sylhetensis, Kuruwa Ghat); T52 ( $P$. sylhetensis, Kushiara river); T3 ( $P$. sylhetensis, Bauxa WLS, West Bengal); C7 ( $P$. tecta, Gomerighat; T7 (P. tecta, Hajo); C4 ( $P$. tecta, Kushiara river); T26 (P. tentoria Lahorighat); T27 (P. tentoria flaviventer, Lahorighat); T49 (P. tentoria, Hajo); T13 ( $P$. tentoria circumdata, Ganga river); T12 ( $P$. tentoria circumdata, Ganga river); T15 ( $P$. tentoria circumdata,Yamuna river); T16 ( $P$. tentoria circumdata,Yamuna river); T1 (P. smithii, Morigaon); T50 ( $P$. smithii, Deeporbeel); T2 (P. smithii, Burhachapari WLS); $\mathrm{C} 15$ ( $P$. smithii pallidipes, Ganga river); $\mathrm{C} 12$ ( $P$. smithii, Biswanathghat); ' $a$ ' and 'b' represents sample replicates of respective species from the same locality.]

understanding of population genetic structure of Pangshura.

\section{ACKNOWLEDGEMENTS}

The authors are thankful to the Ministry of Environment and Forests, Government of India and the state forest departments of Assam, West Bengal and Uttar Pradesh for necessary permission to carry out the research. The Principal, St. Anthony's College, Shillong, Meghalaya, India is acknowledged for providing the laboratory facilities at the Biotechnology department. The authors gratefully acknowledge the Department of Biotechnology, 


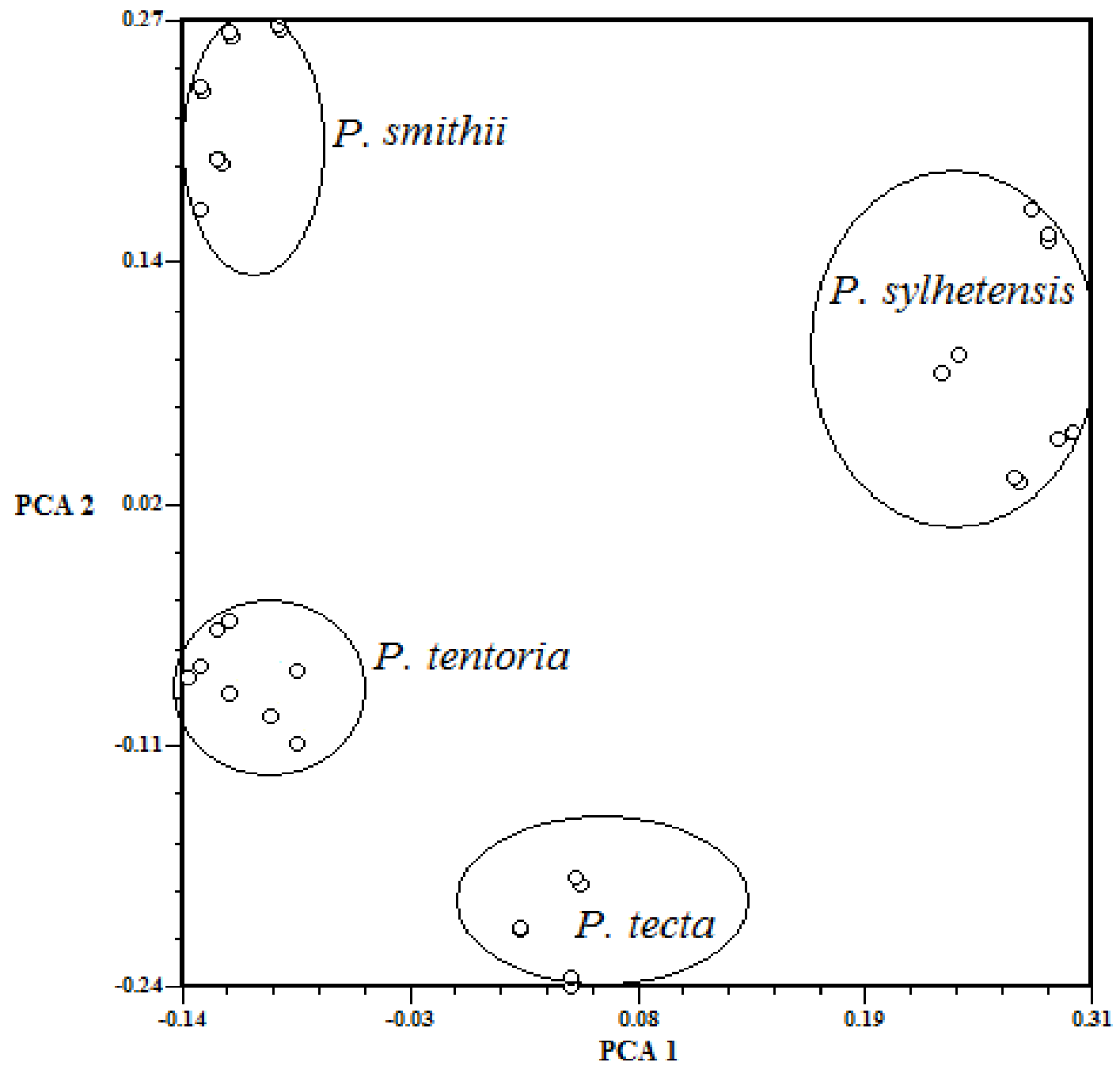

Figure 4. Plot of the first two principal components in Principal Components Analysis of ISSR data from Pangshura species mentioned in the plot. $P$. sylhetensis, T3, T8, T28, C10, T52; P. tecta, C4, C7, T7 C4; P. tentoria, T12, T13, T15, T16, T26, T27, T49; P. smithii, T1, T2, T50, C12, C15].

Government of India for the financial support to establish the Bioinformatics Infrastructure Facility (BIF). The authors are very grateful to Asutosh Triapthi of TSAIndia for providing the samples.

\section{REFERENCES}

Aggarwal RK, Velavan TP, Udaykumar D, Hendre PS, Shanker K, Choudhury BC, Singh L (2004). Development and characterization of novel microsatellite markers from the olive ridley sea turtle (Lepidochelys olivacea). Mol. Ecol. Notes. 4:77-79.

Ausubel FM, Brent R, Kingsten RE, Moore DD, Seidman JG, Smith JA, Struhl K (1995). Short Protocols in Molecular Biology (third Ed.), John Wiley and Sons, New York.

Avise JC (2004). Molecular Markers, Natural History and Evolution (Second Edition). Sinauer, Sunderland, MA.

Baruah C, Sarma PK, Sharma DK (2010). Status and conservation of Assam roofed turtle Pangshura sylhetensis in the Brahmaputra floodplain, Assam, India. NeBIO 1(3):42-47.

Baruah C (2010). In situ conservation of endangered freshwater turtles through community participation programmes in the riverine chars (islands) of Brahmaputra, Assam, India. Final Report submitted to Rufford Small grant, UK. p. 36.

Berry O, Tocher MD, Sarre SD (2004). Can assignment tests measure dispersal? Mol. Ecol. 13:551-561.

Berry KH, Morafka DJ and Murphy RW (2002). Defining the desert tortoise(s): Our first priority for a coherent conservation strategy. Chelonian Conserv. Biol. 4:249-262.

Bornet B, Branchard M (2001). Non-anchored simple sequence repeat markers: reproducible and specific tools for genome fingerprinting. Plant Mol. Biol. Reporter 19:209-215.

Bowen BW and Avise JC (1996). Conservation of marine turtles. In: Avise J.C. and Hamrick J.L. (Ed.) Conservation genetics: Case Histories from Nature (pp 190-237). Chapman and Hall, New York. Buhlmann KA, Akre TSB, Iverson JB, Karapatakis D, Mittermeier RA, Georges A, Rhodin AGJ, van Dijk PP, Gibbons JW (2009). A global analysis of tortoise and freshwater turtle distributions with identification of priority conservation areas. Chelonian Conserv. Biol. 8(2):116-149.

Buntjer JB (2001). Phylogenetic Computer Tools Version 1.32 for Windows. Laboratory of Plant Breeding, University of Wageningen, Wageningen, Netherlands. 
Burns CE, Ciofi C, Beheregaray LB, Fritts TH, Gibbs JP, Márquez C, Milinkovitch MC., Powell JR,Caccone A (2003). The origin of captive Galápagos tortoises based on DNA analysis: implications for the management of natural populations. Anim. Conserv. 6:329-337.

Chen Q, Wang CH, Lu G, Song X, Xu JW., Yang QL, Li SF (2009). Analysis of genetic variation in grass carp (Ctenopharyngodon idellus) from native and colonized regions using ISSR markers. Biochem. Sys. Ecol. 37:549-555.

Choudhury BC, Bhupathy S, Fahmeeda H (2000). Status Information on the Tortoises and Freshwater Turtles of India. pp. 86-94 in Asian Turtle Trade: Proceedings of a Workshop on Conservation and Trade of Freshwater Turtles and Tortoises in Asia (van Dijk, Stuart \& Rhodin,eds.). Chelonian Res. Monographs, Number 2.

Condit R, Hubbell SP (1991). Abundance and DNA sequence of twobase repeat regions in tropical tree genomes. Genome 34:66-71.

Crim JL, Spotila LD, Spotila JR (2002). The leatherback turtle Dermochelys coriaceae, exhibits both polyandry and polygyny. Mol. Ecol. 11:2097-2106.

Das I (2001). Die Schildkröten des Indischen Subkontinents. Chimaira, Frankfurt am Main, p. 181

Das I (2002). A photographic guide to snakes and other reptiles of India. New Holland Publishers (UK) Ltd., London. p. 144.

Drummond AJ, Ashton B, Buxton S, Cheung M, Cooper A, Heled J, Kearse M, Moir R, Stones-Havas S, Sturrock S, Thierer T, Wilson A (2010). Geneious v5.1 web. www.geneious.com.

Edwards T, Goldberg CS, Kaplan ME, Schwalbe CR , Swann DE (2003). PCR primers for microsatellite loci in the desert tortoise (Gopherus agassizii, Testudinidae). Mol. Ecol. Notes 3:589-591.

Felsenstein J (2004). Phylip (Phylogeny Inferance Package), ver. 3.6. Computer program distributed by the author. Department of Genome Sciences, University of Washington, Seattle, Washington, USA. Web. http://evolution.genetics.washinghton.edu/phylip.html.

Fritz U, Guicking D, Auer M, Sommer RS, Wink M, Hundsdorfer AK (2008). Diversity of southeast Asian leaf turtle genus Cyclemys: how many leaves on its tree of life? Zool. Scripta 37(4):367-390.

Guicking D, Joger U, Wink M (2009). Cryptic diversity in a Eurasian water snake (Natrix tessellata, Serpentes: Colubridae): evidence from mitochondrial sequence data and nuclear ISSR-PCR fingerprinting. Organisms Divers. Evol. 9:201-214.

Gupta M, Chyi YS, Romero-Severson J, Owen JL (1994). Amplification of DNA markers from evolutionary diverse genomes using single primers of simple-sequence repeats. Theor. Appl. Genet. 89:9981006.

IUCN [International Union for the Conservation of Nature and Natural Resources] (2011). IUCN Red List of Threatened Species. Web: www.iucnredlist.org.

Janzen FJ, Hoover SL, Shaffer HB (1997). Molecular phylogeography of the Western Pond Turtle (Clemmys marmorata): preliminary results. Chelonian Conserv. Biol. 2(4):623-626.

Kuo CH, Janzen FJ (2004). Genetic effects of a persistent bottleneck on a natural population of ornate box turtles (Terrapene ornata). Conserv. Genet. 5:425-437.

Meloni M, Perini D, Filigheddu R, Binelli G (2006). Genetic variation in five mediterranean populations of Juniperus phoenicea as revealed by Inter-Simple Sequence Repeat (ISSR) markers. Anal. Bot. 97:299304.

Nei M (1972). Genetic distance between populations. Am. Nat. 106:283-292.

Nei M (1973). Analysis of gene diversity in subdivided populations. Proc. Natl. Acad. Sci. U.S.A. 70:3321-3323.

Nei M (1978). Estimation of average heterozygosity and genetic distance from a small number of individuals. Genetics 89:583-590.

Nei M, Li WH (1979). Mathematical model for studying genetic variation in terms of restriction endonucleases. Proc. Natl. Acad. Sci. U.S.A. 76:5269-5273

Nichols RA, Freeman KLM (2004).Using molecular markers with high mutation rates to obtain estimates of relative population size and to distinguish the effects of gene flow and mutation: a demonstration using data from endemic Mauritian skinks. Mol. Ecol. 13:775-787.
Praschag P, Hundsdorfer AK, Fritz U (2007). Phylogeny and taxonomy of endangered South and South-east Asian freshwater turtles elucidated by mtDNA sequence variation (Testudines: Geoemydidae: Batagur, Callagur, Hardella, Kachuga, Pangshura). Zool. Scripta 36:429-442.

Ratnaparkhe MB, Santra DK, Tullu A, Muehlbauer FJ (1998). Inheritance of inter simple sequence repeat polymorphism and linkage with fusarium wilt resistance gene in chickpea. Theor. Appl. Genet. 96:348-353.

Rohlf FJ (2005). NTSYS-pc: Numerical taxonomy and multivariate analysis system, ver. 2.2, Setauket, NY.

Russello MA, Glaberman S, Gibbs JP, Marquez C, Powell JR, Caccone A (2005). A cryptic taxon of Galápagos tortoise in conservation peril. Biol. Lett. 1:287-290.

Saitou N and Nei M (1987). The Neighbor-joining method: a new method for reconstructing phylogenetic trees. Mol. Biol. Evol. 4:406425.

Schwartz TS, Karl SA (2005). Population and conservation genetics of the gopher tortoise (Gopherus polyphemus). Conserv. Genet. 66:917-928.

Schwartz TS, Osentoski MF, Lamb T, Karl SA (2003). Microsatellite loci for the North American tortoises (genus Gopherus) and their applicability to other turtle species. Mol. Ecol. Notes 3:283-286.

Shrestha TK (2001). Herpetology of Nepal: A study of amphibians and reptiles of the trans- Himalayan Region of Nepal, India, Pakistan and Bhutan. Bimala Shrestha Publishers, Nepal.

Souza FL, Cunha AF, Oliveira MA, Pereira GA, Pinheiro HP (2002). Partitioning of molecular variation at local spatial scales in the vulnerable Neotropical freshwater turtle, Hydromedusa maximiliani (Testudines, Chelidae): implications for the conservation of aquatic organisms in natural hierarchical systems. Biol. Conserv. 104:119126.

Tautz D, Renz M (1984). Simple sequences are ubiquitous repetitive components of eukaryotic genomes. Nucleic Acids Res. 12:41274138.

Tsumura Y, Ohba K, Strauss SH (1996). Diversity and inheritance of inter-simple sequence repeat polymorphisms in Douglas fir (Pseudotsuga menziesii) and sugi (Cryptomeria japonica). Theor. Appl. Genet. 92:40-45.

Van Dijk PP, Stuart BL, Rhodin AGJ (2000). Asian Turtle Trade. Proceedings of a Workshop on Conservation and Trade of Freshwater Turtles and Tortoises in Asia, Phnom Penh, Cambodia, 1-4 December 1999. Chelonian Res. Monographs 2:1-164.

Waldick RC, Kraus S, Brown M, White BN (2002). Evaluating the effects of historic bottleneck events: an assessment of microsatellite variability in the endangered North Atlantic right whale. Mol. Ecol. 11:2241-2249.

Wolfe AD, Xiang QY, Kephart SR (1998). Assessing hybridization in natural populations of Penstemon (Scrophulariaceae) using hypervariable inter simple sequence repeat markers. Mol. Ecol. 7:1107-1125

Wu KS, Jones R, Danneberger L, Scolnik PA (1994). Detection of microsatellite polymorphisms without cloning. Nucleic Acids Res. 22:3257-3258

Yeh FC and Boyle T (1997). POPGENE Ver 1.32. (www.ualberta.ca/_fyeh) Microsoft window based freeware for population genetic analysis.

Zietkiewicz E, Rafalski A, Labuda D (1994). Genome fingerprinting by simple sequence repeat (SSR)-anchored polymerase chain reaction amplification. Genomics 20(2):176-83. 